\title{
EMPLOYEE PERCEPTION IN INDIAN TOURISM SECTOR TOWARDS THE IMPACT OF HRM PRACTICES ON EMPLOYEE EMPOWERMENT
}

\author{
Dr. Srijib Shankar Jha \\ Associate Professor, Department of Travel \& Tourism Management, Siliguri Institute of Technology, \\ Sukna, District: Darjeeling (W.B), Pin code: 734009
}

Article DOI: https://doi.org/10.36713/epra7951

DOI No: 10.36713/epra7951

\begin{abstract}
Many companies have recently focused their efforts on developing strategies to improve individual contributions to the overall success of the organisation. Several authors examined the links between several HRM practise components and their effects on the efficiency of employees. While the fact that HRM is favourably linked to organisational and workforce performance is well known, the relationship between HRM and performance in the Indian context is also increasingly understandable. This work will examine how far performance management system factors, particularly employee empowerment, are associated with employee attitudes. Both quantitative and qualitative methods have been used in this study. Structured questionnaires have been used in four companies to collect information from 200 employees based on information received from the literature review. The results show that employee empathy with most aspects of HRM practises is favourable and significantly related.
\end{abstract}

KEYWORDS : performance management, retention, employee attitude, human resource management.

\section{INTRODUCTION}

Many organisations have been working in recent years to find ways to strengthen their commitment to the overall success of the organisation. This crucial operation is described by the term "performance management." Performance management (PM) has evolved as an increasingly complete complex estimate and management framework from a mix of executive reviews and implementation estimate frameworks. Organizational performance management systems became more and more complex, incorporating different factors than financial indicators and focusing on the long-term viability of the organisation. The research on the hierarchical estimation and execution of both the association and the individual board has been steadily increasing since the mid-1990s (Thorpe and Beasley, 2004; Neely, 1999).

Personal resource performance management includes activities such as joint objectives and progress review, and frequent communication, feedback and coaching on improved performance, implementation of employee development programmes and rewarding achievements. When a new employee joins a system, the performance management process starts and ends when an employee quits the company. Performance management can be defined as a systemic procedure to improve the overall performance of an organisation by improving the performance of an individual in a team structure. Definite job description; linking employee to organisational goals by clear and measurable performance expectations; planning training and development of skills; coaching practises; regular performance evaluation and evaluation - these are all key practises in performance management systems (PM system) (Murphy and Cleveland, 1996; Arvey and Murphy, 1998; DeNisi, 2000; Graham, 2004; Armstrong and 
Baron, 2004). The performance of employees is regularly monitored and evaluated and forms part of a broader strategy of regular communications with employees.

\section{THE INDUSTRY OF TOURISM AND HOSPITALITY}

Tourism and hospitality, one of the largest service industries in the world, have long been important for human society. In order to experience another environment and acquire new knowledge, the desire to visit other areas in and out of one's country has existed from old times. Tourism includes all the phenomena and relationships that arise from the links between tourists, host and communities, businesses and NGOs involved in the attraction, transportation, hosting and management of tourists and other visitors. In recent decades, tourism continued to grow and diversify, and became one of the fastest-growing economic sectors in the world. Tourism now generates the same income as oil, food and car exports. Tourism has become one of the leading international trading participants and one of many developing countries' primary sources of income and employment. The global expansion of tourism in many allied industries, including building, agriculture and telecommunications, has led to economic and labour increases. The tourism industry is India's largest service industry, accounting for 6.23 percent of the national GDP and 8.78 percent of total employment. India receives approximately five million international tourists and 562 million domestic tourists each year. Around USD 28.50 billion were made available in foreign exchange by India's tourism industry in 2018. (Source: Ministry of Tourism statistics, Indian Government, 2018).

The Indian business of tourism and hospitality has a strong future, but is confronted with major human resources problems including a shortage of trained personnel at the operational and management levels, as well as a wide difference in supply and demand. Moreover, in the most industry organisations, there is no professionalism, as demonstrated by low wages, long working hours, an unsuitable trajectory of career, the lack of professional development, the lack of training and development and, to name but a few, an improper work-life balance. Managing employee performance is one of the toughest challenges facing tourism and hospitality companies today as it relies entirely on employee devotion, competence and performance clarity. It's widely accepted that employees can be a powerful tool for motivation and development if managed effectively via a well-designed award system and feedback mechanism.

\section{PROBLEM TO INVESTIGATE}

Responses to the "how to priority" and "what is most important" questions appear to be an important research challenge in performance management interventions in the tourism industry. In addition, the following two investigation questions appear relevant, given the lack of investigation into how many parts of performance management work together to empower employees:

1. Does effective performance management genuinely produce the attitudes and responses required to achieve best possible results?

2. What are the barriers to successful implementation of performance management?

The study is important for tourism enterprises because it shows how performance management can modify business processes and support the development of a stable and reliable Indian business system. Research will help understand and identify factors that affect the performance of individuals and organisations. Research results will be used to recommend effective approaches to tourism to reduce the attraction, leadership, motivation, dedication and performance of employees.

\section{LITERATURE REVIEW}

In Boselie et al. (2005), Katou, and Budhwar (2006), numerous international studies show the parallels and contradictions of HRM and performance research. They also show that there were a number of studies. In Huselid's factor analysis (1995) indexes of highly involved human resources management practises were developed and validated. The relationship between highly involved human resources management practises and various organisational performance measures, including attachment to work, corporate financial performances and productivity, was strong and positive. Delaney and Huselid (1996) found that practises consistent with a highly involved strategy in human resource management, such as highly selective recruitment, incentive compensation and training, had positive implications for corporate performance in another study. Following empirical research, the relationships between the extent to which a firm adopts highly engaging human resources management strategies and organisational results have become reasonably strong and positive (MacDuffie 1995; Delery and Doty 1996; Youndt, Snell, Dean and Lepak 1996; Huselid, Jackson and Schuler 1997; Ichniowski et al. 1997; Chadwick and Cappelli 1998; Katou and Budhwar 2007). 
Many authors have investigated the relationship between individual management of human resources and corporate financial performance. Lam and White, for instance (in 198), found that the human resources orientations of firms are linked with increased asset return, sales growth and stock value growth, as measured by effective recruitment, overaverage compensation and extensive training and development. Richard and Johnson (2001) examined a number of performancy variables using a sample of banks for the effect of strategic resource management (ratios of how effective a variety of human resource practises have been performed). They found that the efficacy of strategic human resources management was directly related to employee turnover and that for banks with higher capital intensity the relationship between this metric and equity returns was stronger.

Training is essential to improve competitiveness (Fairfield Sonn, 1987), to improve the quality of output (Holzer et al., 1993), to facilitate corporate growth and to increase profitability, according to studies which show a positive impact on firm performance (Bartel, 1994). In his opinion, training seems to improve all aspects of corporate performance, including product quality and product development, relationships between employees, sales growth, profitability and market share. Kalleberg and Moody (1994). Training is also regarded as a valuable tool to adapt to changes caused by innovation in technology, market competition, organisational structure and demographic change (Knoke and Kalleberg, 1994). The relationship between employment training programme adoption and financial performance established by Russel, Terborg and Power (1985). Performance assessment helps improve business operations, efficiency (Alexander, 1989), elimination of defects (Youndt et al., 1996), reliability and productivity of products (Alexander, 1989). (Alexander, 1989). [Redman, 1993; Cassio., 1989]. The positive correlation between four variables of evaluation (informal frequency of evaluation, objective criteria use, and use of subjective criteria and results) and firm performance was found by Martell et al. (1996). In a study by 3000 businesses around the world, Roberts (1995) demonstrated that an advanced, professional evaluation system can improve employee performance and corporate profitability substantially. Employment and compensation performance assessments (Borman 1991) were also consistently linked with increased company profits (Gerhart and Milkovich 1990). Koch and McGrath (1996) reported a higher productivity of work in companies that had more advanced staffing practises (planning, recruitment and selection). The relationship between incentive compensation systems and firm performance implies that compensation incentives contribute to improving quality of product, increasing change acceptance and improving company performance (Hiltrop, 1996; Luthans, 1998). Murphy (1985) examined the relationship between firm performance and incentive compensation for the 461 exceedances of 72 companies over the 18-year period, founding that both shareholder returns and sales growth are significantly and positively related to the executive compensation, which includes both salaries and bonuses as well as stock optionen, stock holdings and deferred compensation.

In the United States and most recently in the United Kingdom over the last decade, the research on human resources management and performance has been conducted. The question arises, however suitable, whether US and UK-centered models remain in other contexts. In recent years, numerous researchers from abroad have built on this foundation to contribute to this literature. Harel and Tzafrir (1999) have found that the practise of human resources in both public and private organisations in Israel is linked to the perceived performance of the organisation and the market. In a sample of Korean companies, Lee and Miller (1999) found a correlation between human resources practise and performance. Bae, Chen, Wan, Lawler and Walumba (2003) found that high-performance work systems worked efficiently, although under very variable conditions in their research on human resources strategy in Pacific Rim countries. A sample of Japanese companies have found that Morishima (1998) widely accepts the contingency perspective. Ngo, Turban, Lau, and Lui (1998) have found that a high degree of engagement has tended to increase organisational performance in Hong Kong companies in certain working practises (training and compensation technologies). Tsai (2006) found that effective employee empowerment practises correlate positively with Taiwan's business performance. Zheng, Morrison and O'Neill (2006) examined high-level human resource management in 74 Chinese SMEs to find that only a high-level employee commitment was identified as a critical outcome in the area of human resources management to increase performance, despite performance-based pay, participatory decisionmaking, free market selection and performance evaluation.

\section{METHODOLOGY OF RESEARCH}

Probability sampling is used in this research, as every element of the universe has an equal chance of being included in the sample in this sampling design. Since the sample population is not a homogeneous group, a stratifying sampling technique is applied to obtain a representative sample. The population is divided into several populations known as individually more homogeneous strata than the overall population under stratification 
sampling. Each strata contains a proportional number of samples so that each organisation is properly represented, regardless of its size. The probability sampling method is used, therefore, to survey a total of 200 managers and managers of four travel companies in the eastern part of India, e.g. Thomas Cook, India Ltd., Kuoni India, Yatra.com, Club, and 7 holiday days. Sampling is a proportionately stratified random sampling method.

Through a structured questionnaire, employees of various positions of Indian travel companies have been surveyed to learn about how they view and how they perform on performance management. To ensure that each of the four selected organisations had a proportional representation, the same percent of respondents were selected, from the total organisational managers and managers. Different strata or range were categorised and a proportionate number of samples from within each strata were randomly selected based on the years of experience in that organisation. Since most of the organisations selected above are employed by 50 to 150 , a good percentage was taken to represent the total number of employees and would provide a fair amount of data for study. Quantitative data were obtained by using a 5-point Likert scale answer format from the questionnaire. Via "2 = strongly in agreement with the statement" the verbal anchors went from "-2 = strongly opposed to the statement."

\section{Dependent variable}

\section{VARIABLES}

\begin{tabular}{|l|ll|}
\hline \multicolumn{1}{|c|}{ Variable } & \multicolumn{1}{c|}{ Description } \\
\hline $\begin{array}{l}\text { Employee } \\
\text { empowerment }\end{array}$ & $\begin{array}{l}\text { Loyalty: The extent to which employees are committed to work for the company. } \\
\text { Identification: The extent to which employees treat the company as if it were their own } \\
\text { and feel hopeful, motivated and enthusiastic about the company. }\end{array}$ \\
& $\begin{array}{l}\text { Involvement: The extent to which employees are willing to exert considerable effort } \\
\text { and do their best to take the company forward. }\end{array}$ \\
\hline
\end{tabular}

Independent variables

\begin{tabular}{|l|l|}
\hline \multicolumn{1}{|c|}{ Variables } & \multicolumn{1}{c|}{ Description } \\
\hline $\begin{array}{l}\text { Context and } \\
\text { purpose }\end{array}$ & $\begin{array}{l}\text { Awareness - strategy: The extent to which the vision, strategy and the team's } \\
\text { purpose and contribution towards the strategy are communicated and understood. }\end{array}$ \\
\hline $\begin{array}{l}\text { Focus and } \\
\text { responsibility }\end{array}$ & $\begin{array}{l}\text { Specific responsibilities: The extent to which performance requirements are clarified and } \\
\text { agreed on in terms of objectives, goals and measures which are fair, realistic and achievable }\end{array}$ \\
\hline $\begin{array}{l}\text { Skills } \\
\text { development }\end{array}$ & $\begin{array}{l}\text { Current: The extent to which skills requirements for current job effectiveness are specified, } \\
\text { development areas are agreed, and appropriate training / coaching are provided. } \\
\text { Future: The extent to which career plans exist and skills requirements for future job } \\
\text { requirements are developed. }\end{array}$ \\
\hline Resources & $\begin{array}{l}\text { Materials: The extent to which required resources are made available in terms of the physical } \\
\text { working environment and workspace. } \\
\text { Methods: The extent to which required resources are made available in terms of effective and } \\
\text { user-friendly operating systems, processes, job aids, procedure } \\
\text { manuals, policies and checklists. }\end{array}$ \\
\hline feedback & $\begin{array}{l}\text { Feedback frequency: The extent to which feedback is frequent and regular on top of bi-annual } \\
\text { performance discussions } \\
\text { Feedback quality: The extent to which feedback is adequate, gives employees a chance to } \\
\text { explain difficulties, resolve problems and find ways to improve their performance. } \\
\text { Objectivity: The extent to which monitoring and evaluations of performance are fair and based } \\
\text { on facts. }\end{array}$ \\
\hline Consequences & $\begin{array}{l}\text { Perceived link 'performance-reward': The extent to which employees believe that there is a } \\
\text { link between their contribution, reward and remuneration. } \\
\text { Recognition: The extent to which employees feel their efforts are recognized and supported. } \\
\text { Disciplinary approach: The extent to which employees perceive that poor } \\
\text { performance is dealt with. }\end{array}$ \\
\hline
\end{tabular}




\section{HYPOTHESIS}

Positive linear relationships exist between the performance management practices (context, focus, resources, development, monitoring, and consequences) and employee empowerment

\section{DATA ANALYSIS}

The results of the exploratory factor analysis yielded one factor with eigenvalue $=3.67$; explaining $52 \%$ of total variance. Subsequently the employee empowerment sub-scale has passed the uni- dimensionality test.

As depicted in Table 1 an acceptable factor structure was obtained for the employee empowerment sub-scale. Five out of the seven sub-scale items displayed highly satisfactory factor loadings on the first principal component $(-0.709$ to -0.790$)$.

\section{Table 1}

Factor structure of the employee empowerment sub-scale

\begin{tabular}{|l|l|}
\hline $\begin{array}{l}\text { Factor Loadings (Unrotated) } \\
\text { Extraction: Principal components } \\
\text { (Marked loadings are >.700000) }\end{array}$ \\
\hline \multicolumn{2}{|l|}{} \\
\hline Emp. Empower 1 & Factor 1 \\
\hline Emp. Empower 2 & -0.670290 \\
\hline Emp. Empower 3 & $\mathbf{- 0 . 7 0 9 1 9 3}$ \\
\hline Emp. Empower 4 & $\mathbf{- 0 . 7 5 8 6 7 2}$ \\
\hline Emp. Empower 5 & $\mathbf{- 0 . 7 9 0 0 4 1}$ \\
\hline Emp. Empower 6 & -0.599394 \\
\hline Emp. Empower 7 & $\mathbf{- 0 . 7 8 3 1 0 8}$ \\
\hline Eigen value & $\mathbf{- 0 . 7 4 0 0 1 2}$ \\
\hline Expl. Var & 3.672140 \\
\hline & 0.524591 \\
\hline
\end{tabular}

Based on the results discussed above the assumption of a single latent variable underlying the items comprising the employee empowerment sub-scale seems reasonable.

Table 2

Correlations between variables

\begin{tabular}{|l|l|}
\hline $\begin{array}{l}\text { Correlations } \\
\text { Marked correlations are significant at } \mathrm{p}<0.001 \\
\mathrm{~N}=200\end{array}$ & Employee Empowerment \\
\hline & \\
\hline Context & 0.53 \\
\hline Focus & 0.63 \\
\hline Resources & 0.50 \\
\hline Development & 0.63 \\
\hline Monitoring \& Feedback & 0.56 \\
\hline Consequence & 0.62 \\
\hline
\end{tabular}

As seen in Table 2, the results indicate that a substantial (moderate correlation coefficient of between 0.40 and 0.69$)$ and significant $(\mathrm{p}<0.05)$ relationship exists between all the performance management practices and employee empowerment. Substantial positive correlations were reported between context and Emp. Empower $(r=0.53, p<0.05)$; focus and employee empowerment $(r=0.62 ; p<0.05)$; resources and Emp. Empower $(r=0.50 ; p<0.05)$; development and employee empowerment $(r=0.63, p<0.05)$; feedback and employee empowerment $(r=0.56, p<0.05)$; and consequences and employee empowerment $(r=0.63, p<0.05)$. 
Hypothesis, stating that performance management practices have a positive effect on employee empowerment has thus been corroborated.

\section{REGRESSION OF EMPLOYEE EMPOWERMENT ON PERFORMANCE MANAGEMENT PRACTICES}

As indicated in Table 3 employee empowerment was significantly predicted by all six performance management practices, namely consequences $(\mathrm{t}=8.63, \mathrm{p}<0.001)$, development $(\mathrm{t}=6.71, \mathrm{p}<0.001)$, focus $(\mathrm{t}=5.61, \mathrm{p}<$ $0.001)$, resources $(\mathrm{t}=4.49, \mathrm{p}<0.001)$, context $(\mathrm{t}=2.89, \mathrm{p}<0.01)$, and monitoring and feedback $(\mathrm{t}=-2.01 ; \mathrm{p}<$ $0.05)$.

Table 3

Regression of employee empowerment on performance management practices

Regression Summary for Dependent Variable: Commit

$\mathrm{R}=.72419757 \mathrm{R}^{2}=.52446212$ Adjusted $\mathrm{R}^{2}=.52163435$

$\mathrm{F}(6,1009)=185.47 \mathrm{p}<0.0000$ Std.Error of estimate: 3.5896

\begin{tabular}{|l|l|l|l|l|l|l|}
\hline & \multicolumn{1}{|c|}{ Beta } & $\begin{array}{c}\text { Std. Err. Of } \\
\text { Beta }\end{array}$ & \multicolumn{1}{|c|}{ B } & Std. Err. Of B & \multicolumn{1}{|c|}{ t } & p-level \\
\hline Intercept & & & 0.462942 & 0.289684 & 1.598091 & 0.110336 \\
\hline Context & 0.090636 & 0.031324 & 0.108496 & 0.037496 & 2.893544 & 0.003891 \\
\hline Focus & 0.213850 & 0.038087 & 0.154770 & 0.027565 & 5.614759 & 0.000000 \\
\hline Resources & 0.122648 & 0.027297 & 0.120924 & 0.026914 & 4.493047 & 0.000008 \\
\hline Development & 0.237253 & 0.035377 & 0.164332 & 0.024504 & 6.706449 & 0.000000 \\
\hline Mnt Fdback & -0.076187 & 0.037843 & -0.054942 & 0.027291 & -2.013226 & 0.044356 \\
\hline Consequence & 0.280670 & 0.032531 & 0.295873 & 0.034293 & 8.627890 & 0.000000 \\
\hline
\end{tabular}

Together the six performance management practices could account for $52.44 \%$ of the variance in employee empowerment scores.

Based on the findings reflected in Table 3, Hypothesis, stating that performance management practices (context, focus, resources, development, monitoring and consequences) can be used to predict employee empowerment has been corroborated.

\section{CONCLUSIONS}

The primary objective of the study was to analyse the links between methods of performance management and the empowerment of employees in the Indian tourist industry and the relative importance of different strategies in produced these results. For this purpose the hypotheses put forward by a theoretical model were empirically examined. This finding means that managers who effectively deliver context and purpose, focus and responsibility, development opportunities, resources, monitoring and feedback on performance and effects as defined by the Shirley (2005) model of high performance practises are associated with employees who are highly satisfied.

Employees are dedicated more closely to working environments where their goals are strategically relevant in terms of the organization's plans and objectives, have a high level of participation in setting goals, perceive their goals to be clear and receive frequent literature and empirical studies performance bonuses. This finding is in addition consistent with the literature, which suggests employees are more involved in a workplace where managers articulate a vision, promote the acceptance of group objectives, set high-performance expectations, provide individualised support and challenge employees to think in new ways about problems and work challenges, all of which involve measures. Employees are more engaged in an environment where management/managers assign or secure agreements on what needs to be done, monitor differences in standards, take corrective actions and, in return, promise or reward employees for completing satisfactorily the assignment.

\section{REFERENCES}

1. Amba-Rao, S.C., Petrick, J.A., Gupta, J.N.D., and Von der Embse, T.J. (2000), 'Comparative Performance Appraisal Practices and Management Values among Foreign and Domestic Firms in India,' International Journal of Human Resource Management, 11, 1, 60-89.

2. Amaratunga, D., \& Baldry, D. (2002). Moving from performance measurement to performance management. Facilities, 20 (5/6), 217-223. 
3. Alexander, F (1989). Performance appraisals. SmallBusiness Reports, 14(3), 20-29.

4. Bae, J., Chen, S., Wan, T.W.D., Lawler, J.J., and Walumba, F.O. (2003), 'Human Resource Strategy and Firm Performance in Pacific Rim Countries,' International Journal of Human Resource Management, 14, 8, $1308-1332$.

5. Bartel, AP (1994). Productivity record from the implementation of employee training programs.

6. Becker, B.E. and Huselid, M.A. (1998), 'High performance work systems and firm performance: A synthesis of research and managerial implications.' In Personnel and Human Resource Management, v16, pp. 53-101.

7. Bhatnagar, J., and Sharma, A. (2005), 'The Indian Perspective of Strategic HR Roles and Organizational Learning Capability, ' International Journal of Human Resource Management, 16, 9, 1711-1739.

8. Borman, WC (1991). Job behavior, performance, and effectiveness. In Handbook of Industrial and Organizational Psychology, 2nd edition, MD Dunnette and LM Hough (eds.). Palo Alto: CA Consulting Psychologists Press, 22711326.

9. BROWN, D. and ARMSTRONG, M. 1999. Paying for Contribution. Real Performance-related pay strategies. London: Kogan Page.

10. Budhwar, P., and Sparrow, P. (1998), 'National Factors Determining Indian and British PERFORMANCE MANAGEMENTPractices: An Empirical Study, 'Management International Review, 38, Special Issue 2, $105-121$.

11. Casio, WF (1989). Managing Human Resources, 2nd ed. New York: McGraw-Hill.

12. Chadwick, G., and Cappelli, P. (1998), 'Investments or Contracts? The Performance Effects of Human Resource Systems under Contingencies, 'working paper, Wharton School, University of Pennsylvania, Philadelphia.

13. Delaney, J.T., and Huselid, M.A. (1996), 'The Impact of Human Resource Management Practices on Perceptions of Organizational Performance, 'Academy of Management Journal, 39, 4, 949-969.

14. Delery, J and D Doty (1996). Mode of theorizing in strategic human resources management: Tests of universalistic, contingency, and configurational performance predictions. Academy of Management Journal, 39(4), 802-35.

15. Dyer, L and T Reeves (1995). Human resource strategies and firm performance: What do we know and where do we need to go? International Journal of Human Resource Management, 6(3), 656-670.

16. Fletcher, C. (2001). Performance appraisal and management: The developing research agenda. Journal of Occupational and Organisational Psychology, 74 (4), 473-488.

17. Fletcher, C., \& Williams, R. (1996). Performance Management, Job Satisfaction and Organisational Commitment. British Journal of Management, 7, 169-179.

18. FURNHAM, A. 2004. Performance managementSystems. European Business Journal. 83 - 94.

19. Gerhart, B. (2005), 'Human Resources and Business Performance: Findings, Unanswered Questions and an Alternative Approach,' Management Revue, 16, 174-185.

20. Gerhart, B and GI Milkovich (1992). Employee compensation: Research and practice. In Handbook of Industrial and Organizational Psychology, MD Dunnette and LM Hough (eds.). Palo Alto: Consulting Psychologists Press.

21. GOLEMAN, D. 1996. Emotional Intelligence. Why it can matter more than IQ. London: Bloomsbury Publishing.

22. Griliches, Zvi, "Introduction" in Zvi Griliches, ed., Output Measurement in the Service Sector, NBER Studies in Income and Wealth Volume 56, University of Chicago Press, 1992.

23. Harel, G.H., and Tzafrir, S.S. (1999), 'The Effect of Human Resource Management Practices on the Perceptions of Organizational and Market Performance of the Firm, ' Human Resource Management, 38, 3, 185-200.

24. Hiltrop, SM (1996). The impact of human resource management on organizational performance: Theory and research. European Management Journal, 14(6), 628-637.

25. Ichniowski, C., Shaw, K., and Prennushi, G. (1997), 'The Effects of Human Resource Management Practices on Productivity: A Study of Steel Finishing Lines, 'American Economic Review, 87, 3, 291-313.

26. Katou, A., and Budhwar, P. (2006), 'The Effect of Human Resource Management Systems on Organizational Performance: Test of a Mediating Model, 'International Journal of Human Resource Management, 17, 7, $1223-1253$.

27. Kalleberg, AL and JM Moody (1994). Human resource management and organizational performance. The American Behavioral, 37(7), 948-962. Luthans, $K$ (1998). Using PERFORMANCE MANAGEMENTto compete in the 2lst century. Management Quarterly, 38(4), 17-22.

28. KAPLAN, R.S. and NORTON, D.P. 1992. The Balanced Scorecard-measures that drive performance. Harvard Business Review. 70(1):71-79.

29. KAPLAN, R.S. and NORTON, D.P. 1996. Linking the Balanced Scorecard to Strategy. Harvard: Harvard Business School Press.

30. Keep, E. and Mayhew, K. (1999) The Leisure Sector (Skills Task Force Research Paper 6), DfEE.

31. Khandwalla, P. (2002), 'Effective Organizational Response by Corporates to India's Liberalization and Globalization,' Asia Pacific Journal of Management, 19, 2/3, 423-448.

32. Koch, M.J., and McGrath, R.G. (1996), 'Improving Labor Productivity: Human Resource Management Policies Do Matter,' Strategic Management Journal, 17, 5, 335-354.

33. Kock, R., Roodt, G., \& Veldsman, T.H. (2002). The alignment between effective people management, business strategy and organisational performance in the banking and insurance sector. South African Journal of Industrial Psychology, 28 (3), 83-91.

34. Kotter, J.P., \& Heskett, J.L. (1992). Corporate culture and performance. New York: The Free Press. 
35. Krishna, A., and Monappa, A. (1994), 'Economic Restructuring and Human Resource Management,' Indian Journal of Human Relations, 29, 490-501.

36. Lawler, J.J., Jain, H.C., Venkata Ratnam, C.S., and Atmiyanandana, V. (1995), 'Human Resource Management in Developing Economies: A Comparison of India and Thailand,' The International

37. Martell, $K$ and SJ Carroll (1995). Which executive human resource management practices for the top management team are associated with higher firm performance? Human Resource Management, 34(4), 497-512.

38. Murphy, KJ (1985). Corporate performance and managerial remuneration: An empirical analysis. Journal of Accounting and Economics, 7(1-3), 11-42.

39. Morishima, M. (1998), 'Changes in Japanese Human Resource Management: Implications for Firm Performance,' paper presented at Workplace Conflict and Cooperation: Prospects for Employee Representation, University of Urbana-Champaign, 1-2 May.

40. NEELY, A., GREGORY, M. and PLATTS, K. 1995. Performance measurement system design. A literature review and research agenda. International Journal of Operations and Production Management. 15(4):80-116.

41. Ngo, H.-Y., Turban, D., Lau, C.-M., and Lui, S.-Y. (1998), 'Human Practices and Firm Performance of Multinational Corporations: Influences of Country of Origin, International Journal of Human Resource Management, 9, 4, 632-652.

42. Paul, A.K., and Anantharaman, R.N. (2003), 'Impact of People Management Practices on Organizational Performance: Analysis of a Causal Model,' International Journal of Human Resource Management, 14, 7, $1246-1266$.

43. Pratt, H.J. (1991). Principles of Effective Performance Management. Records Management Quarterly. Vol. 23 No.1. 28. -33 .

44. Richard, O.C., and Johnson, N.B. (2001), 'Strategic Human Resource Management Effectiveness and Firm Performance, ' International Journal of Human Resource Management, 12, 2, 299-310.

45. Riley, M., Gore, J. and Kelliher, C. (2000) 'Economic determinism and human resource management practice in the hospitality and tourism industry', Tourism and Hospitality Research, 2(2), 118-128.

46. Russel, J.S., Terborg, J.R., and Powers, M.L. (1985), 'Organizational Performances and Organizational Level Training and Support,' Personnel Psychology, 38, 849-863.

47. Roberts, $K$ (1995). The proof of human resource is in the profits. People Management, 1(3), 42-43.

48. Sangweni, S.S. (2003). Performance managementas a Leadership and Management Tool. Senior Management Services Conference. 15 -17 June.

49. Schuler, R.S., and Jackson, S.E. (2005), 'A Quarter-century Review of Human Resource Management in the US: The Growth in Importance on the International Perspective, 'Management Revue, 16, 11-35.

50. Singh, K. (2003), 'Strategic HR Orientation and Firm Performance in India,' International Journal of Human Resource Management, 14, 4, 530-543.

51. Som, A. (2006), 'Bracing MNC Competition Through Innovative PERFORMANCE MANAGEMENTpractices: The Way Forward for Indian Firms,' Thunderbird International Business Review, 48, 2, 207-237.

52. Spangenberg, H.H., \& Theron, C.C. (2001). Adapting the Systems Model of Performance Management to major changes in the external and internal organisational environments. South African Journal of Business Management, 32 (1), 35-47.

53. Stashevsky, S., \& Koslowsky, M. (2006). Leadership team cohesiveness and team performance. International Journal of Manpower, 27 (1), 63-74.

54. Steyn, A.G.W., Smit, C.F., Du Toit, S.H.C., \& Strasheim, C. (1995). Moderne Statistiek vir die Praktyk. Pretoria: Van Schaik Publishers.

55. Theron, C.C., \& Spangenberg, H.H. (2000). Confirmatory factor analysis of the performance management audit questionnaire. South African Journal of Psychology, 30 (4), 32-39.

56. THORPE, R. and BEASLEY, T. 2004. The characteristics of performance managementresearch. Implications and challenges. International Journal of Productivity and Performance Management. 53(4):334-344.

57. TOBIN, D.R. 1998. The knowledge-enabled organization. Moving from 'Training' to 'Learning' to Meet Business Goals. New York: Amacom.

58. Tsai, C.-J. (2006), 'High Performance Work Systems and Organizational Performance: An Empirical Study of Taiwan's Semiconductor Design Firms, 'International Journal of Human Resource Management, 17, 9, $1512-1530$.

59. Tsui, A.S., Pearce, J.L., Porter, L.W. and Tripoli, A.M. (1997). 'Alternative approaches to the employee-organisation relationship: does investment in employees pay off?' In Academy of Management Journal, v40, pp. 1089-21.

60. Venkatraman, N., and Ramanujam, V. (1986), 'Measurement of Business Performance in Strategy Research: A Comparison of Approaches, 'Academy of Management Review, 11, 801-814.

61. Van Dijk, \& H.C. Thornhill, C. (2003). Implementing Performance M anagement to enhance Development. South Africa Journal of Public Administration. Vol.38. 464-467.

62. Williams, R.S. (2002). Managing Employee Performance. Design and Implementation in

63. Organisation.2nd ed. Singapore: Senge Lee Press.

64. Youndt, MA, SA Snell, JW Dean and DP Lepak (1996). Human resource management, manufacturing strategy, and firm performance. Academy of Management Journal, 39(4), 836-866. 